УДК 657.6:334.012.46(045)

DOI: https://doi.org/10.32782/2413-9971/2019-28-31

\author{
Kostiuchenko Nataliia \\ Candidate of Economic Sciences \\ in World Economy and International Economic Relations
}

Костюченко Н. П.

кандидат економічних наук

за спеціальністю світове господарство та міжнародні економічні відносини

\title{
CHANGE IN GOVERNANCE IN NON-PROFIT BOARD OF DIRECTORS AS A KEY TO EFFECTIVE PERFORMANCE
}

Summary. The article suggests a scientific approach to determine the factors affecting strategic results of non-profit organizations. It provides an analysis of scientific publications concentrating on the question of a change in governance, analyzing the types of motivations, incentives and expertise of the future board members as factors that will improve the performance of the company. The most recent studies prove that philanthropic giving has become a tool in improving performance of the companies and achieving better economic results. The question of change in governance is seen as an important challenge to face, because the studies provide evidence on the importance of the prevalence of intrinsic motives over extrinsic ones, strong leadership abilities, education as well as managerial and accounting expertise. In this work the concept of governance is strictly addressed to the context of non-profit organizations, paying considerable attention to the board characteristics. Literature findings provide that public and non-profit employees are similarly motivated by intrinsic rewards. Literature provides evidences form many studies about education as a factor, defining a choice of work in a non-profit sector. The most recent research provides that information technology is one of the skills that board members don't possess. Apart from that, accounting and managerial expertise are seen as the key driver to effective achievement of company goals. It was revealed that expertise, experience and social relations are the most desired capabilities in NPO board members.

Key words: non-profit governance, philanthropy, BoD, motivation, expertise.

Introduction. The foundations of charitable activities were laid back in times of Cicero and Seneca. Maintenance of moral obligations in front of population was one of the ultimate tasks of philanthropy at that time, proclaiming it as a sort of instrument of securing social justice. There is a lot of discussion in scientific literature about strategic philanthropy and a role of the board capital in contributing to effective governance, achievement of organizational mission and its advanced performance. The object of our research is the change in governance of non-profit organizations. The subject of our research is the identification of factors that have to be taken into account when assigning new BoD members in order to improve the performance of a non-profit organization.

Analysis of recent research and publications. Nowadays, a trend of aligning business objectives and strategies with philanthropic giving has become more popular and widely used. Scientific research provides a lot of evidences on active use of philanthropy. Potential benefits of corporate philanthropy have 
been documented in many studies (Sandfort, 2008). A strategic approach to philanthropy has been widely adopted; however, little research has been done on this matter (Campbell \& Slack, 2008; Saiia, Carroll, \& Buchholtz, 2003). A trend of adoption of strategic philanthropy has proven that companies consider philanthropy as a strategic activity.

The topic of strategic philanthropy is still young and not well-studied. The effect of philanthropic giving on financial performance has been the most popular argument among scientists in this field (Godfrey, 2005; Porter and Kramer, 2002). Scientists tried to shed light on the extent to which firms are strategic in their giving (Brammer et al., 2006; Saiia et al., 2003). Motivations for firms to participate in strategic philanthropy have received attention in academic world as well.

Unsolved parts of the general problem. The article provides a major contribution to the extant non-profit literature by building on an important organizational issue: change in governance, incentives and expertise of future candidates. It provides a review of non-profit literature by studying a change in governance, non-profit board members' incentives and expertise and how these factors influence organizational performance.

The aim of this article is analysis of existing literature in order to investigate how to choose new BoD members to impact the performance of non-profit positively.

Main part of the research. The emergence of a third sector, made up of organizations which are neither seeking profit nor are a part of the public sector, appeared in the mid-1970s. Up until that point, there wasn't a distinct third sector: there were mentioning and developing the notions about co-operatives in the twentieth century literature and then in the late 1960 s, there were used the notions about workers' co-operatives and the so-called 'labor-managed firms'. It has stimulated appearance of theoretical and empirical findings in neoclassical economy.

Non-profit governance is an issue that has gained more attention in recent years. First of all, it is important to define some terms adopted in the article that are crucial in further developing of the topic.

Non-profit organizations are the independently constituted organizations that do not distribute profits to shareholders, even though it may be desirable for them to produce surpluses to create tomorrow's working capital or judicious reserves. Many of them are Incorporated Associations or Limited Companies (e.g. in Australia), although they may also be Aboriginal Corporations or other legal entities. The sector is variously referred to as the non-profit sector, not-for-profit sector, voluntary sector or Third Sector (Fishel, 2008, p.3). In America, the concept of non-profit sector is deeply rooted in history and is associated with a term 'independent sector'. The early growth of voluntary associations in the USA is attributed to the «deep-seated hostility to royal power and centralized state authority». An idea of the non-profit sector as a separate mechanism of public interests regulation took shape in the end of the nineteenth century. As a result, it became possible to realize public needs using this kind of organizations. Overall, the non-profit organizations contribute to the community where they operate by addressing economic, social, and environmental concerns.

Generally speaking, the concept of governance in its own right has emerged since times, when humans learned how to gather into communities and live in accordance with certain laws. They would choose the wisest leader who would adopt the rules of behavior inside of the group in order to guarantee a harmonious existence and fairness in decision-making.

The term «governance» has a wide usage and connotation among various contexts. For instance, it is common in the political economy literature, considering globalization processes. That is why it is a complex and multi-faceted term. In order to define it correctly, it is important to understand the context in which it is applied. Governance is the arrangements for overall control and direction of the organization, normally in the form of authority conferred by the membership (or key stakeholders) on a board or committee. One of the most important elements of successful performance of the organization is a well-organized work of its board. It has to be adapted to both internal and external circumstances of the organization. Board is defined as the governing body of the organization, the group of people who have ultimate accountability for and authority over the organization, subject to the will of the members. Here the term «board» refers to the governing body, regardless of the nature of the legal entity. Boards are robust and effective social systems. The board has to accept responsibility for its own standards in order to be honest and effective (Fishel, 2008). There is a great variety of types of internal governance organization in non-profits. Sometimes, there is no board or the whole board may consist of one person only. However, there are also examples when there is an elaborate supervisory board, which fulfills all the appropriate functions and monitors the CEOs. But when we speak about non-profits, we shall keep in mind the peculiarities of these organizations, such as absence of owners, limited legal accountability as well as lack of transparency. It may happen that the board consists of volunteers who don't receive any salary. In this case there is a danger of passiveness of the board members. In fact, board members are often expected to contribute in monetary terms to the non-profit organization where they work other than be paid. Apart from this, there is also a problem of pressure from the side of the founding family members who might express desire to become board members and influence governance decisions, blocking the minority board members.

It is important to realize the motivation of the board members to provide good governance and successful performance in a non-profit organization. A study of Inglis and Cleave (2006) suggests a framework consisting of six «intangible attributes» for good governance:

1. self-esteem;

2. learning through community;

3. helping the community;

4. individual relationships;

5. unique contributions to the board;

6. self-healing.

There are different incentives guiding individuals who want to dedicate themselves to a work in a certain sector. Work motivation may vary depending on hierarchical levels in the company (Buelens \& Van den Broeck, 2007). The reputation of the company was confirmed to be one of the most important motivations (Chen, 2014). Moreover, one should distinguish between «intrinsic» and «extrinsic» rewards. Under the first one there are implied those benefits derived from the satisfaction an individual receives from performing a task (autonomy, achievement, social contacts, opportunities to learn), while the latter means those given by others (wage, promotion, job security). Literature findings provide that public and non-profit employees are similarly motivated by intrinsic rewards (Suh, 2018).

According to a global survey of employees, elements that nurture their engagement are:

- belief in the organization's mission and vision;

- promising future for one's self;

- work-life balance;

- confidence in the leaders of organization;

- good on-the-job training, education and development opportunities;

- being treated with respect and dignity (Graziano, 2018). 
A feeling of attachment was identified later as one of the reasons to serve for board. For example, 4 factors including growth, responsibility, contribution, and recognition. The relations factor was added to them later on, emphasizing personal and professional social ties. Later on another study suggested a scale of six factors identifying the motivations of board members: enhancement of self-worth, learning through community, helping the community, developing individual relationships, unique contributions to the board, and self-healing (Walton et al., 2017). Serving on the board of directors is defined as a leadership position (Mannino et al., 2011).

A study of Coombes et al. (2011) was concentrated on the non-profit boards, particularly their behavioral orientations. Board service can provide leadership skills, networking opportunities and prestige. National Index of Non-profit Board Practices survey acknowledged that boards need to strengthen recruitment of board members to improve board performance (Tysiac, 2018). There is a need to understand motivations and aspirations of candidates.

Literature provides evidence from many studies about education as the factor, defining a choice of work in a non-profit sector. There is the evidence that provides that more educated individuals are more likely to volunteer or work for nonprofits. A study of Suh (2018) provides that the education-job match is only significant for individuals whose first job was in for-profit sector; and public employees are more likely to move to non-profit sector if their intrinsic job rewards are gratifying. This study is concentrated only on entry-level employees.

There are a lot of evidences in literature to describe that the for-profit firms use monetary incentives to motivate employees in comparison to non-profit ones (Leete, 2000). However, employees in non-profit sector prefer to provide «labor donations» and have lower wages, but a higher job satisfaction of the social benefit they contribute. (Borzaga\&Tortia, 2006).

The expertise required by the board is an important element to consider. A variety of skills shall be represented across the board. Nowadays, as to the 2018 survey conducted by executive and board member search and training firm JWC Partners, information technology expertise is the skill with the least level of representation in boardroom. Information technology is one of three skills that board members don't possess. Today, with a rising need in data analytics and artificial intelligence development, issues related to technological competencies as well as cybersecurity are extremely important. It is possible to diversify the board composition by targeting technology experts in the recruiting process. Later on, such professionals can be trained in other areas of board responsibilities.

A study of Qiao (2018) is concentrated on the accounting expertise of the board members. A multivariate regression analysis was used to test the main hypothesis. It was found that accounting expertise of board members helps to smooth corporate dividend payment and increase the advising role.

Adams et al. (2018) found increased levels of firm performance given the commonality in directors' skill sets. In other words, the ability of directors' skills to add value partly depends on other skills that are represented on the board. The study uses Tobin's Q to measure diversity of skills and its relation to the performance of the firm. The study took into consideration a number of skills, among which there is a technology one. The most common skills among firms according to the study are the finance and accounting as well as management and leadership. Technology skill is in the middle of the rating.

Roshayani et al. (2018) used a resource based view theory (RBV) and revealed that expertise, experience and social relations are the most desired capabilities in NPO board members. The authors see usage of capabilities at all levels with the pursuit of achieving competitive advantage through innovation. Posses- sion of such resources would accomplish a firm's implementation of its competitive advantage and improved efficiency. This paper refers to the UK Institute of Directors (IOD) that provides a director competency framework build around three dimensions: knowledge, skills and mind-set. Apart from that, the Organization for Economic Co-operation and Development (OECD) provides a summary of important capabilities that contribute to overall success. There are three clusters: delivery related capabilities required to achieve results; interpersonal capabilities required to build relationships; strategic capabilities that relate to future planning. However, the Australian Institute of Company Directors (AICD) state that the effective governance requires the following skills of directors that cover the following domains: behavioral, governing, technical and industrial. Furthermore, the Governance Institute of Australia produced a «Good Governance Guide» as a guide to create a skills matrix for its BoDs. It includes, but is not limited to the following criteria: executive and non-executive experience; industry and sector experience or knowledge; subject matter expertise; strategic thinking; governance; geographic experience and leadership. Moreover, the US Sarbanes-Oxley Act (SOX) of 2002 requires at least one financial expert when creating an audit committee.

Another interesting finding was that $37 \%$ of directors believed that cyber risk expertise was a very important attribute. The research was based on the websites and annual reports of Malaysian NPO's. The study supports a concept of «capability for board members» in NPOs, providing evidence from non-profit and for-profit sectors.

Kao (2017) constructed a Taiwan's project management competence scale of 80 items by conducting an empirical research, which included 30 items of technical competence performance of the project management. Hoefer et al. (2013) finds that human service managers require management skills. Apart from that, technical skills of administration are essential for development of students who plan to work in social sector.

Miller at al. (1988) suggests that involvement of the board in various activities brings about to the recruitment of members with a particular type of expertise. The study claims that board composition and activities can make a difference.

Article of Hoefer et al. (2013) examined the preferred job skills for executive director positions from the perspective of board chairs. Business related skills were seen as important in the study.

Board capital was studied by Haynes et al. (2010), particularly, the bundle of resources, skills, and ties the board can put into use for the company and contribute to its effectiveness. Scientists stated that the board's role in strategic change is very important. That is why skills of the board members have a great impact on the outcomes of the organization.

Change in governance. Non-profit leadership in the governing board plays a crucial role in the activities and performance of the organization. Responsibilities of the governing boards are very wide and for this reason the question of succession planning is so important. Board members bring knowledge, skills, perspectives and connections to the organization. There is not much research done on the matter of succession planning of executives in non-profit sector. Another problem is that many top executives are serving for too long at their position, and the Charlotte study reports a concern about the lack of experience in leadership transition (Carman et al., 2010).

Herman and Heimovics (1990) outline that the chief executives are the single most critical factor underlying non-profit effectiveness. They conclude that «the chief executives occupy a place of psychological centrality» and «are assigned and accept responsibility for both successful and unsuccessful outcomes,» whereas «board presidents see themselves as affecting outcomes little» (Herman and Heimovics, 1990, p. 171). 
However, a succession process is a challenge for the non-profit, because this sector is characterized by its unique traits, such as an apparent shortage of experienced executive directors in the job market, lower salaries, lack of organizational infrastructure, an increasingly demanding set of executive tasks, and related issues that make non-profit executive positions potentially less appealing to upcoming Generation $\mathrm{X}$ and $\mathrm{Y}$ leaders.

Definitely, a change of the board member of the non-profit organization, especially its President, is a big stress for the organization, because this person has to perform a pivotal role, a new captain who takes on the responsibility for his ship. Directors protect stockholders' interests as they were appointed by them and hold a fiduciary duty. Directors have a wide range of legal duties.

«Boards that offer orientations to new board members can give them a good start on learning what they need to know to be effective board members. Useful documents for board members include the organization's constitution and bylaws, mission statement, plans, annual reports, goals, budget, financial reports, program descriptions, organizational chart and policies. Additional useful materials for board members are relevant laws, a contact list for board members and committees, committee descriptions, the board member job description, board officer job descriptions, meeting agendas and procedural rules, event schedules, meeting minutes, organizational evaluations, and needs assessments. Board selfassessments can help members to understand their weak areas and identify needs for board development», these are the recommendations provided in the list of Board tools in the book «Managing Non-profit Organizations». Board \& Administrator Journal mentions the following when recruiting new board members: «If you plan to raise money from a tax levy, recruit members with political clout. If your plan depends on major gifts, look for members who have affluence and influence. If you have a special events strategy, include people who are talanted party givers with large groups of friends.»

Introduction of succession planning is important, because it is connected with a higher organizational performance as well as smoother transitions (Giambatista, Rowe, and Riaz, 2005).

A study of McKee et al. (2016) explores factors that may influence executive succession planning in non-profit and cooperative organizations. Their study employed multiple regression analysis. It was found that the elements of governance quality and internal development were possible substitutes for executive succession planning.

It is critical that the board ratifies the emergency plan for the top executive position. The context of succession planning was especially urgent eight years ago and gave rise to many scientific publications on this matter. It was due to a substantial numbers of baby boomers, at that time at the peak of their careers, reached retirement age.

A study of Froelich et al. 2011 concentrated on planning the executive succession. It was found that planning and preparation do not match the level of interest and concern for executive succession. A review of the non-profit literature conducted for this project revealed that non-profit governance and leadership inquiry for boards of directors are more significant than those for executive directors (Froelich et al., 2011).

The Annie E. Casey Foundation report outlines different succession planning models designed for non-profits, developed by leadership transition consultants at CompassPoint Non-profit Services in San Francisco, CA, and at TransitionGuides in Silver Spring, MD, such as:

- strategic leader development: an ongoing practice that involves identification of necessary skills to align with the strategic vision of the company, recruiting and maintaining these individuals;
- emergency succession planning: means a creation of environment in which the key administrative and leadership functions are performed even in case of absence of an administrator;

- departure-defined succession planning: if a leader acknowledges his intention to resign two or three years in advance than it is necessary to identify the goals of the agency, the tools necessary for the successor, careful process of building the capacity of the board, managers, and systems to sustain funding and programs.

CompassPoint's succession planning consultants have developed surveys that help to plan the process. Those include:

- sustainability audit surveys;

- staff survey;

- stakeholder survey;

- strategic leader development plan;

- sample emergency succession plan.

A study of Santora et al. (2015) compares six countries (Australia, Brazil, Israel, Italy, Russia, and the United States) to determine the degree to which succession planning was planned and whether internal or external candidates have been selected as the executive directors. Successors are strongly dominated by outsiders at $57 \%$; only about $38 \%$ of successors are insiders, clearly giving the advantage to outsiders. As our study database is of Italian origin, it is important to mention that Italy was defined as one of the countries with the high power distance societies. House et al. (2004, p. 166) defines it as follows: «in the high power distance societies, power holders are granted greater status, privileges, and material rewards than those without power». Other characteristics of power distance include decision-making styles of bosses, the ability to influence, opportunity to express thoughts freely, and the use of artifacts such as titles, ranks, and status. $60 \%$ of Italian nonprofits gave a negative response when asked whether succession planning activities took place within organization, $90 \%$ responded in support of an insider candidate for a succession with $70 \%$ selected Deputy Director as a potential successor.

The non-profit organization is a complicated mechanism that has its own internal processes different from the for-profit companies. A saying of McFarlan is relevant in this case: «Don't assume the shoe fits,» because "governance of non-profits can differ dramatically from the governance of businesses» (McFarlan, 1999, p. 65). The change in governance process in non-profit is very complicated, because developing internal candidates is not an easy task. Lack of development opportunities was found by Carman et al. (2010), stating that young professionals have only online or free training available. Peculiarities of some nonprofit organization, such as size constraints and lack of resources for internal leadership development force to switch for a better option for succession planning, which means a careful search for candidates outside the organization. For this reason a welldesigned recruitment strategy is especially important.

Conclusions. Based on the literature review it can be concluded that effective governance in non-profits is seen as a powerful vehicle in achieving organization's goals. A change in governance is a serious challenge for a non-profit. Succession planning techniques have to be introduced in order to improve the process. Intrinsic motivation of the $\mathrm{BoD}$ members as well as expertise of the candidates has an important impact on the strategic philanthropy results.

It can be summarized that organizational performance is a final end that let us understand the level of its success. As a result, factors, contributing to accomplishment of organizational goals, such as the social capital of the BoD, effective decision-making practices, evolved leadership styles, essence of a common goal, motivation of members, are important indicators to concentrate on, when formulating strategic direction of the organization and thinking about ways for improvement and further development. 


\section{References:}

1. Adams, R.B., Akyol, A.C., \& Verwijmeren, P. (2018). Director skill sets. Journal of Financial Economics.

2. Borzaga, C., \& Tortia, E. (2006). Worker motivations, job satisfaction, and loyalty in public and nonprofit social services. Nonprofit and voluntary sector quarterly, 35(2), 225-248.

3. Brammer, S., Millington, A., \& Pavelin, S. (2006). Is philanthropy strategic? An analysis of the management of charitable giving in large UK companies. Business Ethics: A European Review, 15(3), 234-245.

4. Buelens, M., \& Van den Broeck, H. (2007). An analysis of differences in work motivation between public and private sector organizations. Public administration review, 67(1), 65-74.

5. Campbell, D., \& Slack, R. (2008). Corporate "philanthropy strategy" and "strategic philanthropy" some insights from voluntary disclosures in annual reports. Business \& Society, 47(2), 187-212.

6. Carman, J.G., Leland, S.M., \& Wilson, A.J. (2010). Crisis in leadership or failure to plan? Insights from Charlotte, North Carolina. Nonprofit Management and Leadership, 21(1), 93.

7. Chen, C.A., Hsieh, C.W., \& CHEN, D.Y. (2014). Fostering public service motivation through workplace trust: Evidence from public managers in Taiwan. Public Administration, 92(4), 954-973.

8. Coombes, S.M., Morris, M.H., Allen, J.A., \& Webb, J.W. (2011). Behavioural orientations of non-profit boards as a factor in entrepreneurial performance: does governance matter?. Journal of Management Studies, 48(4), 829-856.

9. Cornelius M., Corvington P., Ruesga A, (2011). Ready to Lead? Next Generation Leaders Speak Out The Annie E. Casey Foundation. Institution: CompassPoint Nonprofit Services. pp. 36.

10. Fishel, D. (2008). The book of the board: effective governance for non-profit organisations. Federation Press.

11. Giambatista, R.C., Rowe, W.G., \& Riaz, S. (2005). Nothing succeeds like succession: A critical review of leader succession literature since 1994. The Leadership Quarterly, 16(6), 963-991.

12. Godfrey, P.C. (2005). The relationship between corporate philanthropy and shareholder wealth: A risk management perspective. Academy of management review, 30(4), 777-798.

13. Graziano M. (2018). Reimagining Your Hiring Practices: A Self-Assessment. Nonprofit World, 35.

14. Haynes, K.T., \& Hillman, A. (2010). The effect of board capital and CEO power on strategic change. Strategic Management Journal, 31(11), 1145-1163.

15. Herman, R.D., \& Heimovics, R.D. (1990). The effective nonprofit executive: Leader of the board. Nonprofit Management and Leadership, 1(2), 167-180

16. Hoefer, R., Watson, L., \& Preble, K. (2013). A mixed methods examination of nonprofit board chair preferences in hiring executive directors. Administration in Social Work, 37(5), 437-446.

17. Inglis, S., \& Cleave, S. (2006). A scale to assess board member motivations in nonprofit organizations. Nonprofit Management and Leadership, 17(1), 83-101.

18. Leete, L. (2000). Wage equity and employee motivation in nonprofit and for-profit organizations. Journal of Economic Behavior \& Organization, 43(4), 423-446.

19. Mannino, C.A., Snyder, M., \& Omoto, A.M. (2011). Why do people get involved? Motivations for volunteerism and other forms of social action. Social motivation, 127-146.

20. McFarlan, F.W. (1999). Working on nonprofit boards. Don't assume the shoe fits. Harvard Business Review, 77(6), 64-8.

21. McKee, G., \& Froelich, K. (2016). Executive succession planning: Barriers and substitutes in nonprofit organizations. Analysis of Public and Cooperative Economics, 87(4), 587-601.

22. Porter, M.E., \& Kramer, M.R. (2002). The competitive advantage of corporate philanthropy. Harvard business review, 80(12), 56-68.

23. Qiao, Z., Chen, K. Y., \& Hung, S. (2018). Professionals inside the board room: accounting expertise of directors and dividend policy. Applied Economics, 50(56), 6100-6111.

24. Roshayani, A., Hisham, M.M., Ezan, R.N., Ruhaini, M., \& Ramesh, N. (2018). Desired board capabilities for good governance in non-profit organizations. Administration Management Public, (30), 127-140.

25. Saiia, D.H., Carroll, A.B., \& Buchholtz, A.K. (2003). Philanthropy as strategy: When corporate charity "begins at home". Business \& Society, 42(2), 169-201.

26. Sandfort, J. (2008). Using lessons from public affairs to inform strategic philanthropy. Nonprofit and Voluntary Sector Quarterly, 37(3), 537-552.

27. Santora, J.C., Sarros, J.C., Bozer, G., Esposito, M., \& Bassi, A. (2015). Nonprofit executive succession planning and organizational sustainability. The Journal of Applied Management and Entrepreneurship, 20, 66-83.

28. Suh, J. (2018). Human capital inflow in nonprofits: Entry-level employees' sector shift. Nonprofit Management and Leadership, 28(4), 471-489.

29. Tysiac K. (2018), Strategies for maintaining an effective board. Journal of Accountancy.

30. Walton, M.A., Clerkin, R.M., Christensen, R.K., Paarlberg, L.E., Nesbit, R., \& Tschirhart, M. (2017). Means, motive and opportunity: exploring board volunteering. Personnel Review, 46(1), 115--135.

\section{ЗМІНА УПРАВЛІННЯ В РАДІ ДИРЕКТОРІВ ЯК ЗАПОРУКА ЕФЕКТИВНОЇ ДІЯЛЬНОСТІ НЕПРИБУТКОВОЇ ОРГАНІЗАЦІї}

Анотація. У статті запропоновано науковий підхід до визначення факторів, що впливають на стратегічні результати діяльності неприбуткових організацій. У статті наведено аналіз наукових публікацій, зосереджених на питанні зміни в управлінні, типах мотивацій, стимулів та компетентності майбутніх членів правління як факторів, які покращать результати роботи компанії. Останні дослідження доводять, що філантропія стала інструментом підвищення ефективності компаній та досягнення кращих економічних результатів. Питання зміни в управлінні розглядається як важливий виклик, з яким слід зіткнутися, оскільки дослідження свідчать про важливість внутрішніх мотивів, сильних лідерських здібностей, рівня освіти, а також управлінського та бухгалтерського досвіду. Організація управління в будь-якому суспільстві повинна забезпечувати прозорість, здійснюючи економічні, політичні та адміністративні повноваження. У цій роботі концепція управління суворо адресована контексту некомерційних організацій, приділяючи значну увагу 
характеристикам ради директорів. Важливо розуміти мотивацію членів ради для того, щоб забезпечити належне управління та успішну діяльність в неприбутковій організації. Результати досліджень в науковій літературі доводять, що державні та некомерційні працівники аналогічно мотивуються внутрішньою винагородою. Служба в раді директорів визначається як лідерська посада. Література надає докази з багатьох досліджень, які свідчать, що рівень освіти є одним з рішучих факторів присвячення себе роботі в неприбутковому секторі. Останні дослідження свідчать, що інформаційні технології - це одна 3 навичок, якими члени ради не володіють. Крім того, бухгалтерський та управлінський досвід розглядаються як ключовий рушій для ефективного досягнення цілей компанії. Було виявлено, що навички, досвід роботи та соціальні відносини є найбільш бажаними характеристиками членів правління НКО. Наразі існує потреба налагодження зв'язків між лідерами проектів та соціальними інвесторами. Впровадження досвіду європейських країн для економічного та соціального прогресу є одним із можливих шляхів розвитку для України.

Ключові слова: управління, філантропія, рада директорів, мотивація, компетентність.

\section{ИЗМЕНЕНИЕ УПРАВЛЕНИЯ В СОВЕТЕ ДИРЕКТОРОВ КАК ЗАЛОГ ЭФФЕКТИВНОЙ ДЕЯТЕЛЬНОСТИ НЕКОММЕРЧЕСКОЙ ОРГАНИЗАЦИИ}

Аннотация. В статье предложен научный подход к определению факторов, влияющих на стратегические результаты деятельности неприбыльных организаций. В статье приведен анализ научных публикаций, сосредоточенных на вопросе изменения в управлении, типах мотивации, стимулов и опыта будущих членов правления как факторов, которые улучшат результаты работы компании. Последние исследования доказывают, что филантропия стала инструментом повышения эффективности компаний и достижения лучших экономических результатов. Вопрос изменения в управлении рассматривается как важный вызов, с которым следует столкнуться, поскольку исследования свидетельствуют о важности внутренней мотивации, сильных лидерских качествах, уровня образования, а также управленческого и бухгалтерского опыта. В этой работе концепция управления строго адресована контексту некоммерческих организаций, уделяя значительное внимание характеристикам совета директоров. Результаты исследований в научной литературе доказывают, что государственные и некоммерческие работники аналогично мотивируются внутренним вознаграждением. Последние исследования предполагают, что информационные технологии - это одна из навыков, которым члены совета не обладают. Кроме того, бухгалтерский и управленческий опыт рассматриваются как ключевой двигатель для эффективного достижения целей компании. Было обнаружено, что навыки, опыт работы и социальные отношения являются наиболее желаемыми характеристиками членов правления НКО.

Ключевые слова: управление, филантропия, совет директоров, мотивация, компетентность. 